Grażyna Gzella Instytut Informacii Naukowej i Bibliologii Uniwersytet Mikołaja Kopernika w Toruniu e-mail: gmg@umk.pl

\title{
Kościańskie, Iwowskie i poznańskie losy Sylwestra Czarneckiego
}

DOI: http://dx.doi.org/10.12775/TSB.2016.001

STRESZCZENIE: Sylwester Czarnecki (1877-1923) w pierwszych latach swego życia zawodowego zajmował się dziennikarstwem, pracując w redakcjach poznańskiego „Orędownika”, gliwickiego „Głosu Śląskiego”, „Dziennika Polskiego” w Dortmundzie i „Gazety Polskiej” w Kościanie. Gdy liczne wyroki w procesach prasowych groziły osadzeniem go w więzieniu, uciekł najpierw do Krakowa, a potem do Lwowa, gdzie przebywał do zakończenia pierwszej wojny światowej. W 1919 r. wrócił do Wielkopolski i osiadł w Poznaniu. Na stanowisku sekretarza miejskiego pracował do śmierci.

SŁowA KLuczowe: „Gazeta Polska”, Czarnecki Sylwester, Kościan, Lwów, prasa polska, zabór pruski.

\footnotetext{
$S_{x}^{\prime}$ ledząc życiorysy polskich redaktorów zaboru pruskiego przełomu XIX i XX w., można zauważyć ich dużą mobilność, wynikającą z zaangażowania zawodowego, narodowego i patriotycznego. Ludzie prasy nie tylko szukali dla siebie zatrudnienia w różnych prowincjach państwa niemieckiego, ale również przemieszczali się z powodu utraty pracy po wyroku w procesie prasowym, gdy ich miejsce zajęli inni dziennikarze, bądź z obawy przed konsekwencjami swych działań publicystycznych i społecznych, a to nierzadko zmuszało do emigracji nawet poza granice kraju.
} 
Przykładem redaktora, który w swym życiu przeżył konsekwencje wszystkich tych zawiłości losu, był Sylwester Czarnecki pracujący w redakcjach Poznania, Gliwic, Dortmundu i Kościana, emigrant we Lwowie i wreszcie, po odzyskaniu przez Polskę niepodległości, urzędnik miejski w Poznaniu.

Czarnecki urodził się 27 grudnia 1877 r. w wielkopolskim Śremie ${ }^{1}$ jako syn przybyłej do zaboru pruskiego z Litwy Marianny Czarneckiej (1855-1935), później Frankowskiej². Czarneccy do Poznania przybyli w lipcu 1878 r. i w mieście tym przyszły redaktor zdobył wykształcenie. Ukończył, jak sam napisał, sześć klas szkoły średniej, dwa lata uczył się w szkole handlowej i dwa lata pobierał naukę w szkołach uzupełniających $^{3}$. W latach 1898-1900 odbył służbę wojskową w Wittembergu (prowincja saska $)^{4}$. Kolejne lata to praca dziennikarska w różnych redakcjach i różnych prowincjach państwa niemieckiego. Szlify dziennikarskie zdobył w poznańskim piśmie Romana Szymańskiego „Orędownik”, którego był współpracownikiem. W początkach 1903 r. podpisywał numery tej gazety jako redaktor odpowiedzialny ${ }^{5}$. Następnie znalazł się w Gliwicach w redakcji „Głosu Śląskiego”, piśmie Józefa Siemianowskiego. Gdy 1 kwietnia 1904 r. w Dortmundzie wydano pierwszy numer „Dziennika Polskiego", jego redaktorem odpowiedzialnym został Czarnecki . Periodyk z podtytułem „Pismo poświęcone sprawom politycznym, społecznym i ekonomicznym wychodźców polskich w Westfalii i Nadrenii”, z dodatkiem „Niedziela” i w cenie kwartalnej 1,50 marki ukazywał się drukiem i nakładem Ignacego Żnińskiego. Kłopoty finansowe twórcy pisma spowodowały, że w lutym 1905 r. dalszym jego wydawaniem zajęła się spółkaº,

${ }^{1}$ Archiwum Państwowe w Poznaniu [dalej: APP], Urząd Stanu Cywilnego Śrem obwód miejski, sygn. 13.

2 APP, Akta miasta Poznania. Kartoteka ewidencji ludności 1870-1931 [dalej: Kartoteka], sygn. 14339, 14406; Zgony, „Dziennik Poranny” nr 66 z 18 V 1935.

3 APP, Akta miasta Poznania, sygn. 433: Akta osobowe pracowników Zarządu Miejskiego w Poznaniu z okresu międzywojennego (1919-1939).

${ }^{4}$ Tamże.

${ }^{5}$ Bibliografia historii Polski XIX i XX wieku. T. 3: 1865-1918, vol. 2, Warszawa 2010, s. 115.

${ }^{6}$ APP, Akta miasta Poznania, sygn. 433.

7 Numer ten znajduje się w zbiorach Biblioteki Kórnickiej, sygn. Cz. 4325.

8 Wiadomości miejscowe i potoczne, „Orędownik” nr 38 z 16 II 1905; Wiadomości miejscowe i potoczne, „Dziennik Poznański” nr 39 z 17 II 1905. 
a Czarnecki w czerwcu tego roku na krótki czas został nawet redaktorem naczelnym tego periodyku9. Pobyt w Dortmundzie trwał do 7 grudnia 1905 r., gdy opuścił to miasto, wyjeżdżając do Kościana ${ }^{10}$.

$\mathrm{Z}$ dniem 1 stycznia $1906 \mathrm{r}$. został redaktorem odpowiedzialnym kościańskiej „Gazety Polskiej”, będącej kontynuacją wydawanej od 4 października 1896 r. „Gazety Kościańskiej”"11. Czarnecki obowiązki swe objął po Idzim Świtale ${ }^{12}$, redaktorze znanym mu z Dortmundu, gdy razem tworzyli numery „Dziennika Polskiego”"13.

Kościański okres w życiu Czarneckiego okazał się czasem niezwykle trudnym i pełnym konfliktów prasowych ${ }^{14}$.

Już po trzech miesiącach pobytu w tym mieście Czarnecki po raz pierwszy stanął przed sądem. Proces dotyczył biblioteki należącej do Towarzystwa Gimnastycznego „Sokół” przeznaczonej dla dzieci, której

9 Wiadomości miejscowe i potoczne, „Dziennik Poznański” nr 126 z 3 VI 1905; Wiadomości miejscowe i potoczne, „Orędownik” nr 127 z 4 VI 1905; Wiadomości miejscowe i potoczne, „Orędownik” nr 146 z 29 VI 1905.

10 APP, Prezydium Policji w Poznaniu [dalej: PP], sygn. 4947.

11 „Gazeta Kościańska” wydawana była do 8 marca 1902 r., kiedy to zastąpiła ją „Gazeta Polska”. Periodyk ten początkowo redagował i drukował Teodor Bobowski w Kościanie, a wydawcą był Joachim Sołtys w Zabrzu. Gdy kolejne procesy prasowe zmusiły Sołtysa do rezygnacji z dalszego wydawania „Gazety”, od 1 października 1902 r. pismo dalej wydawał Bobowski, a od listopada „Drukarnia Spółkowa”. Zob.: Bibliografia historii..., s. 52-53 tam mylnie rozdzielono „Gazetę Polską” Sołtysa od tej wydawanej jako kontynuacja „Gazety Kościańskiej”. Zob. też.: APP, PP, sygn. 4947; Wydawnictwo „Gazety Polskiej” w Kościanie, „Gazeta Polska” nr 77 z 27 IX 1902.

12 Świtała w Kościanie pracował od 1 stycznia 1905 r. Poszukuje się, „Orędownik” nr 286 z 14 X 1904. Po wyjeździe z Kościana podjął pracę w poznańskiej „Pracy”. Oświadczenie, „Praca” 1905, nr 53, s. 1723; Wiadomości miejscowe i potoczne, „Orędownik” nr 3 z 5 I 1906.

${ }^{13}$ Idzi Świtała z dniem 15 czerwca 1904 r. rozpoczął współpracę z „Dziennikiem Polskim” w Dortmundzie. Wiadomości miejscowe i potoczne, „Orędownik” nr 138 z 18 VI 1904; Polska, „Gazeta Toruńska” nr 141 z 23 VI 1904.

14 Szczątkowość informacji o historii kościańskiego periodyku wiąże się z niemal całkowitym brakiem roczników gazety, po latach zachowało się bowiem niewiele numerów tego pisma. W Bibliografii historii Polski XIX i XX wieku podano, że nr 6 z 1909 r. znajduje się w Bibliotece im. Zielińskich w Płocku, nr 274 z tegoż roku w Muzeum w Chorzowie, a nr 211 z 1913 r. w Bibliotece Kórnickiej PAN w Kórniku. Ponadto, numery 1-78 z 1902 r. udało się odnaleźć w Bibliotece Narodowej Akademii Nauk Ukrainy we Lwowie. Wszystkie zachowane numery pisma z okresu istnienia gazety do $1914 \mathrm{r}$. przynoszą niewiele informacji o składzie redakcji w kolejnych latach. Dopiero źródła pośrednie - gazety wydawane w tym samym czasie - poszerzają, chociaż też niekompletnie, naszą wiedzę o kościańskim periodyku. Bibliografia historii..., s. 53. 
policja poszukiwała już od pewnego czasu. Towarzystwo, chcąc uniknąć kłopotów, podarowało ją Czarneckiemu, a policja za nielegalne, jej zdaniem, wypożyczanie książek skierowała sprawę do sądu. Pierwszy wyrok opiewał na 10 marek kary grzywny bądź 2 dni więzienia ${ }^{15}$. Po ogłoszeniu wyroku redaktor zapowiedział złożenie wniosku apelacyjnego i w kwietniu kościański sąd dopatrzył się racji redaktora i uwolnił go od winy i kary ${ }^{16}$.

Gdy sąd rozpatrywał apelację redaktora, ten wiedział już o kolejnym grożącym mu procesie, będącym efektem walki polskich gazet o zachowanie polskiego stanu posiadania na wsi. Gdy właściciel Łuszkowa koło Śremu sprzedał swoje dobra Komisji Kolonizacyjnej, najpierw gnieźnieński „Lech”, a za nim „Gazeta Polska” opisały to zdarzenie, czym poczuł się obrażony Müller, właściciel folwarku ${ }^{17}$. W pierwszych dniach maja $1906 \mathrm{r}$. odbyło się posiedzenie sądu w Kościanie. Po przesłuchaniu świadków sąd odroczył sprawę do 15 maja, ponieważ - jak napisano w „Orędowniku” - „na terminie wtorkowym wyszły podobno na jaw sprawy, które niekorzystne rzucają światło na postępowanie p. Müllera przy sprzedaży swego folwarku"18. Niestety, nie udało się odnaleźć informacji, jaki ostatecznie wyrok zapadł $\mathrm{w}$ tej sprawie. Polskie gazety nie poinformowały swych czytelników o decyzji sądu kościańskiego, jednak ten brak zainteresowania sprawą świadczyć może, że i tym razem Czarnecki został uwolniony od winy i kary.

W numerze 48 „Gazety Polskiej” z 1 marca 1906 r. zamieszczono artykuł dotyczący „iluminacji w Kościanie z powodu srebrnego jubileuszu małżeńskiego pary cesarskiej”. Tekst kończył się listą nazwisk Polaków, którzy wspólnie z innymi mieszkańcami miasta brali czynny udział w tych uroczystościach ${ }^{19}$. Prokuratura dopatrzyła się w tym tzw. grubej swawoli, czyli wykroczenia przeciw $§ 360$ Kodeksu karnego, i skierowała sprawę

15 Wiadomości miejscowe i potoczne, „Orędownik” nr 75 z 1 IV 1906; Wiadomości miejscowe i potoczne, „Dziennik Poznański” nr 76 z 3 IV 1906; Wiadomości miejscowe i prowincjonalne, „Postęp” nr 77 z 4 IV 1906.

16 Wiadomości miejscowe i potoczne, „Dziennik Poznański” nr 92 z 22 IV 1906; Z bliska i z daleka, „Nowiny Raciborskie” nr 48 z 26 IV 1906; Nowiny z naszych i dalszych stron, „Gazeta Gdańska” nr 51 z 1 V 1906; Wiadomości, „Praca” 1906, nr 17, s. 642.

17 Wiadomości miejscowe i potoczne, „Orędownik” nr 76 z 3 IV 1906.

18 Wiadomości miejscowe i potoczne, „Orędownik” nr 102 z 4 V 1906.

19 APP, PP, sygn. 4947. 
do sądu w Kościanie, ten jednak uwolnił redaktora. Ponieważ oskarżyciel nie zgodził się z wyrokiem, sprawa trafiła do Sądu Ziemskiego w Lesznie. Prokurator domagał się dla oskarżonego kary finansowej w wysokości 30 marek lub tygodnia więzienia, ale sędziowie ponownie uwolnili Czarneckiego $^{20}$, z czym dalej nie zgadzał się skarżący ${ }^{21}$. Kolejny raz do sprawy „iluminacji” powrócono 27 września. Tym razem sąd w Lesznie dopatrzył się w inkryminowanym tekście "grubej swawoli” i skazał redaktora na karę grzywny w wysokości 100 marek bądź 10 dni więzienia ${ }^{22}$. Wniosek Czarneckiego o rewizję wyroku został 9 listopada ostatecznie odrzucony ${ }^{23}$.

Gdy zapadały decyzje w sprawie „iluminacji”, redaktor zmagał się z kolejnymi oskarżeniami. Na proces z 16 października złożyły się dwie zaskarżone publikacje. Pierwsza, zamieszczona w numerze 191 pisma informowała o biciu dzieci przez nauczyciela Sowińskiego ${ }^{24}$, drugą poczuł się obrażony Georg Heisig z Krotoszyna, redaktor „Katholische Rundschau"25, gdy Czarnecki polemizował z jego twierdzeniem, że „ziemia kaszubska jest niemiecką i że Kościan na niemieckiej leży ziemi”26. Wyrok był wysoki. Sąd, zgodnie z sugestią prokuratora, skazał redaktora „Gazety Polskiej” na dwa miesiące więzienia ${ }^{27}$. W uzasadnieniu wyroku dodano: „Tylko ze względu na to, że oskarżony jeszcze młodym jest i dotąd

${ }^{20}$ Wiadomości miejscowe i potoczne, „Dziennik Poznański” nr 165 z 22 VII 1906; Wiadomości miejscowe i potoczne, „Orędownik” nr 165 z 22 VII 1906; Wiadomości miejscowe i prowincjonalne, „Postęp” nr 166 z 24 VII 1906.

21 Wiadomości miejscowe i potoczne, „Orędownik” nr 169 z 27 VII 1906; Wiadomości miejscowe i potoczne, „Dziennik Poznański” nr 170 z 28 VII 1906.

22 APP, PP, sygn. 4947; Wiadomości miejscowe i potoczne, „Kurier Poznański” nr 9 z 29 IX 1906; Wiadomości miejscowe i potoczne, „Dziennik Poznański” nr 222 z 29 IX 1906; Wiadomości miejscowe i potoczne, „Orędownik” nr 223 z 30 IX 1906.

${ }^{23}$ APP, PP, sygn. 4947.

24 Tamże; Wiadomości miejscowe i potoczne, „Orędownik” nr 214 z 20 IX 1906.

25 APP, PP, sygn. 4947; Wiadomości miejscowe i potoczne, „Kurier Poznański” nr 11 z 2 X 1906.

${ }^{26}$ APP, PP, sygn. 4947.

27 Tamże; Wiadomości miejscowe i potoczne, „Kurier Poznański” nr 25 z 18 X 1906; Wiadomości miejscowe i potoczne, „Dziennik Poznański” nr 239 z 19 X 1906; Wiadomości miejscowe i potoczne, „Orędownik” nr 239 z 19 X 1906; Wiadomości miejscowe i prowincjonalne, „Postęp” nr 239 z 19 X 1906; Wiadomości z całego świata, „Katolik” nr 125 z 20 X 1906; Z całej Polski, „Polak” nr 126 z 20 X 1906; Nowiny z naszych i dalszych stron, „Gazeta Gdańska” nr 124 z 20 X 1906. 
nie był jeszcze karanym, i w nadziei, że po pierwszej karze więziennej, jaka oskarżonego spotyka, w przyszłości od tak bezwstydnej roboty się powstrzyma, uznał sąd wymierzoną karę jeszcze za dostateczną"28.

Redaktor w tym czasie wiedział o dalszych oskarżeniach. Już 19 września w „Dzienniku Poznańskim” napisano: „Pięć procesów równocześnie o rzekome przestępstwa prasowe wytoczyła prokuratura w Lesznie redaktorowi «Gazety Polskiej» S. Czarneckiemu”29. „Kurier Poznański” 11 października informował: „«Gazecie Polskiej» wytoczono dwanaście procesów, w tym pięć o rzekome podburzanie do nieposłuszeństwa wobec władzy. Przestępstwa dopatrzono się w artykułach dotyczących nauki religii. Oprócz tego skarży gazetę nauczycielka Schubert o obrazę" ${ }^{30}$. Kilka dni później, 17 października, w „Gazecie Polskiej” napisano: „Wczoraj dostaliśmy nowy zapozew na przesłuchy przed sędziego śledczego o rzekome przestępstwo $§ 110$ kodeksu karnego tj. o nawoływanie do nieposłuszeństwa przeciw rozporządzeniom władzy"31. Dnia 27 października kolejny raz czytelnicy mogli przeczytać: „Nawoływania do oporu dopatrzyła się prokuratura w sprawozdaniu «Gazety Polskiej» z wiecu kobiet, a mianowicie w ustępie, w którym wyrażono nadzieję, że matki Polki z pewnością zastosują się do rad i wskazówek mówczyni wiecowych"32. Wobec dalszych losów redaktora odpowiedzialnego kościańskiej gazety trudno dziś odnaleźć informacje o skutkach oskarżeń skierowanych wobec niego. Wiadomo jedynie, że 13 listopada skazano Czarneckiego na miesiąc więzienia za opublikowanie odezwy pod tytułem „Będzie wojna czy nie?" zachęcającej do przedpłaty ${ }^{33}$.

Gdy zapadał ten ostatni wyrok, redaktora nie było już w Kościanie. W obawie o wysokość kar, jakie mogły zostać na niego nałożone, nie odsiedziawszy jeszcze dwóch miesięcy więzienia, na jakie został skazany, po dziesięciu miesiącach pobytu w mieście, w pierwszych dniach listo-

28 APP, PP, sygn. 4947.

29 Wiadomości miejscowe i potoczne, „Dziennik Poznański” nr 213 z 19 IX 1906.

${ }^{30}$ Walka o naukę religii, „Kurier Poznański” nr 19 z 11 X 1906. 0 liczbie procesów wytoczonych Czarneckiemu informowała też redakcja „Gazety Gdańskiej”. Nowiny z naszych i dalszych stron, „Gazeta Gdańska” nr 121 z 13 X 1906.

31 APP, PP, sygn. 4947.

32 Wiadomości miejscowe i potoczne, „Kurier Poznański” nr 33 z 27 X 1906.

33 APP, PP, sygn. 4947. 
pada Czarnecki wyjechał za granicę ${ }^{34}$, a decyzja ta wywołała burzę wśród redaktorów gazet polskich komentujących ten fakt.

Jako pierwsza zareagowała redakcja „Gońca Wielkopolskiego”, której opinię cytowały inne gazety polskie. Napisano w niej:

Sylwester Czarnecki, który pracowitym i bezstronnym występowaniem swoim zyskał sobie szacunek i sympatię nie tylko czytelników, ale całej prasy polskiej i szerokich kół społeczeństwa, zawiódł pokładane w nim nadzieje i uciekł za granicę. Uciekł z posterunku, na którym sam dobrowolnie stanął, nie namyśliwszy się zapewne, jakie konsekwencje uciekinierstwo jego może dla wszystkich redaktorów polskich pociągnąć za sobą. Odczuwamy bardzo dobrze, że wydawnictwo „Gazety Polskiej” może go żegnać słowami sympatii i żalu, lecz my podobny krok nazywamy po prostu dezercją i dlatego sądzimy, że jest to wyjątkowy wypadek ucieczki z posterunku, a tym smutniejszy, że p. Sylwester Czarnecki jest młody i samotny ${ }^{35}$.

Cytujące te słowa redakcje „Postępu” i „Dziennika Poznańskiego” w pełni zgodziły się z „Gońcem”, uznały postępowanie Czarneckiego za dezercję, ucieczkę z posterunku, przypomniały, że wielu polskich redaktorów czekają procesy ${ }^{36}$. Gazety te zacytowały również tekst z „Posener Tageblatt”, w którym stwierdzono: „Tak postępują sobie polscy «patrioci»; najprzód podburzają, a potem uciekają, ażeby ujść skutków swej działalności”" ${ }^{37}$. Kilka dni później czytelnicy dowiedzieli się, że prokuratura w Lesznie wysłała za redaktorem przebywającym w tym czasie w Krakowie list gończy ${ }^{38}$.

34 Administracja „Gazety Polskiej” poinformowała o tym fakcie swych czytelników w numerze 253 z 6 listopada 1906 r., a źródłem wiadomości był telegram nadesłany do posła dr. Alfreda Chłapowskiego. Zob.: APP, PP, sygn. 4947. Powtórzyły tę wiadomość: Wiadomości miejscowe i potoczne, „Dziennik Poznański” nr 254 z 7 XI 1906; Wiadomości miejscowe i potoczne, „Kurier Poznański” nr 41 z 7 XI 1906; Wiadomości miejscowe i potoczne, „Orędownik” nr 255 z 8 XI 1906.

${ }^{35}$ Cyt. za: Wiadomości miejscowe i potoczne, „Postęp” nr 255 z 8 XI 1906.

${ }^{36}$ Tamże; Wiadomości miejscowe i potoczne, „Dziennik Poznański” nr 256 z 9 XI 1906.

37 Tamże.

38 Wiadomości miejscowe i potoczne, „Kurier Poznański” nr 45 z 11 XI 1906; Polnische Nachrichten, „Posener Tageblatt” nr 531 z 12 XI 1906; Nasze sprawy, „Orędownik” nr 259 z 13 XI 1906. 
Ucieczka Czarneckiego odbiła się również głośnym echem w Kościanie, gdzie podczas zebrania przedwyborczego do rady miejskiej prezes komitetu wyborczego - dr Stanisław Nowakowski w ostrych słowach skrytykował postępek redaktora. Sprawa stała się przedmiotem zainteresowania prasy, ponieważ zacytowana wypowiedź Nowakowskiego, niezwykle ostra, według niego nie była prawdziwa. Prezes komitetu, cytując za „Postępem”, miał powiedzieć:

W ogóle odznaczyła się „Gazeta Polska” za redakcji p. Czarneckiego tym, że pisała tylko same kłamstwa, bezczelne oszczerstwa, podłe podejrzenia. Redaktor Czarnecki, to łotr skończony, nikczemny przybłęda, podły oszczerca, który w niegodziwej walce kierował się tylko osobistymi względami. A teraz, nabroiwszy tutaj dostatecznie, ucieka za granicę, nie mając odwagi wziąć odpowiedzialności za to, co zrobił, na siebie. To tchórz pospolity, zwyczajny dezerter, który ucieka z posterunku, a którego nie tylko niemiecka, ale także polska prasa potępiła ${ }^{39}$.

Przytoczone słowa były wyjątkowo dosadne, redakcja stwierdziła nawet, że to „za daleko posunięta nienawiść". Podobnego zdania była redakcja „Orędownika” ${ }^{40}$.

W obronie nie mogącego odeprzeć zarzutów redaktora wystąpiło grono obywateli kościańskich, którzy wyrazili oburzenie treścią przemówienia i zauważyli, że narażony na prześladowania redaktor ma prawo żądać od rodaków poparcia i obrony ${ }^{41}$. Również poseł dr Alfred Chłapowski, prezes Rady Nadzorczej Wydawnictwa „Gazety Polskiej”, w oświadczeniu opublikowanym w kościańskim piśmie, a przedrukowanym w „Dzienniku Poznańskim”, bronił redaktora i przypomniał zarówno zapadłe, jak i grożące mu wyroki sądowe ${ }^{42}$.

Cytowany przez prasę Nowakowski nie pozostawił informacji o swym wystąpieniu bez odpowiedzi. Z datą 14 listopada wystosował do „Dzien-

39 Wiadomości miejscowe i potoczne, „Postęp” nr 261 z 15 XI 1906.

40 Nasze sprawy, „Orędownik” nr 262 z 16 XI 1906.

41 Wiadomości miejscowe i potoczne, „Dziennik Poznański” nr 261 z 15 XI 1906.

42 Nasze sprawy, „Kurier Poznański” nr 50 z 17 XI 1906; Nasze sprawy, „Orędownik” nr 264 z 18 XI 1906. 
nika Poznańskiego" odpowiedź, w której przytoczył słowa wypowiedziane przez siebie na zebraniu. W stosunku do kościańskiego pisma redagowanego przez Czarneckiego miał powiedzieć: „«Gazeta Polska» za redakcji p. Czarneckiego wobec komitetu tylko kłamstwami, insynuacjami nikczemnymi, oszczerstwami i wyzwiskami operowała", mówiąc zaś o redaktorze stwierdził: „Lecz nie sądźcie panowie, że pozwolę znieważać oficjalny komitet wyborczy, który bądź co bądź jest władzą wyborczą, lada pismakowi przybłędzie, który nabroiwszy, potem jak tchórz prawdziwy salwuje się ucieczką, a którego dziś nawet prasa ludowa piętnuje jako dezertera, który nie zastanowił się nad konsekwencjami, jakie ucieczka jego mieć może dla polskich redaktorów"43. Podobnie jak Czarneckiego, bronili Nowakowskiego kościańscy obywatele ${ }^{44}$. Prasa poznańska - „Kurier Poznański”, „Orędownik”, „Dziennik Poznański” - cytując zarówno Nowakowskiego, jak i jego obrońców, solidarnie opowiedziała się za redaktorem „Gazety Polskiej”.

Czarnecki po krótkim pobycie w Krakowie przeniósł się do Lwowa i z miastem tym związany był aż do odzyskania przez Polskę niepodległości. Zatrudnienie znalazł w lwowskim Zarządzie Miejskim. Początkowo od 27 lipca 1907 do 31 grudnia 1912 r. pracował jako dietariusz, z dniem 1 stycznia 1913 r. mianowano go starszym kancelistą i na stanowisku tym zatrudniony był do 15 czerwca $1916 \mathrm{r}$. Na oficjała awansował 16 czerwca 1916 r. i pozostawał na tym urzędzie do 31 grudnia 1919 r. Jak poinformowano w jego dokumentacji służbowej: „Uchwałą Rady przybocznej miasta Lwowa zaliczono urzędnikom gminy m. Lwowa 10-miesięczny okres inwazji rosyjskiej we Lwowie podwójnie do awansu i do czasu policzonego do emerytury. Z tego powodu czas służby spędzonej przy Magistracie we Lwowie wynosi 13 lat, 3 miesiące i 3 dni" ${ }^{45}$. Pracując w urzędzie miejskim, dał się poznać jako człowiek obowiązkowy i inteligentny. W jednej z opinii o nim sformułowanej w listopadzie 1913 r. napisano: „Jako pracownik o wybitnej inteligencji jest zatrudniony na razie w dziale ewidencji wojskowej, w której jako biegły w języku niemieckim

43 Wiadomości miejscowe i potoczne, „Dziennik Poznański” nr 263 z 17 XI 1906.

44 Wiadomości miejscowe i potoczne, „Dziennik Poznański” nr 264 z 18 XI 1906; Nasze sprawy, „Kurier Poznański” nr 51 z 18 XI 1906; Korespondencja, „Postęp” nr 265 z 20 XI 1906; Nasze sprawy, „Orędownik” nr 265 z 20 XI 1906.

45 APP, Akta miasta Poznania, sygn. 433. 
potrzebnym do korespondencji z władzami wojskowymi jest i pod tym względem na razie przynajmniej siłą nie do zastąpienia" ${ }^{46}$. Kontakty z wojskiem zaowocowały publikacjami: Powszechny poradnik wojskowy na podstawie ustaw i najnowszych rozporzadzeń o służbie, zasiłkach oraz taksach wojskowych (Lwów 1911) i Ustawy mobilizacyjne, a mianowicie: I Ustawa o dostawianiu koni i wozów. II Ustawa o powinnościach wojennych. III Ustawa o zasiłkach mobilizacyjnych (Lwów 1913). Ponadto efektem pracy we Lwowie były wydane w 1913 r. dwie inne książki: Moja kariera. Praktyczny podręcznik dla c.k. urzędników, praktykantów, podurzędników i sług państwowych w każdym stosunku służbowym z tabelarycznym zestawieniem poborów, diet, pensji emerytalnych itp. Należności według rangi i lat służby oraz Pragmatyka służbowa regulująca stosunek służbowy urzędników i służb państwowych. Mieszkając we Lwowie, pracował również w organizacjach młodzieży i na stanowisku redaktora "Gazety Niedzielnej” 47 , wydawanej jako „pismo dla rodzin katolickich”, organu arcybiskupa Józefa Bilczewskiego ${ }^{48}$.

We Lwowie Czarnecki się ożenił, jego wybranką została Kazimiera z domu Holzschuh, urodzona w tym mieście 4 marca 1892 r. ${ }^{49}$ Małżeństwo pozostało bezdzietne.

Odzyskanie przez Polskę niepodległości pozwoliło podjąć starania o powrót do Wielkopolski. W kwietniu 1919 r. Czarnecki wystosował do Zarządu Miejskiego w Poznaniu podanie o przyjęcie do pracy. Po trwających przez pewien czas negocjacjach dotyczących pensji zapadła decyzja o zatrudnieniu byłego redaktora na stanowisku sekretarza miejskiego (stanowisko równorzędne ze sprawowanym we Lwowie oficjałem) w administracji poznańskiej ${ }^{50} .25$ grudnia 1919 r. opuścił Lwów i dotarł do Poznania ${ }^{51}$, zamieszkał u matki, a 2 stycznia 1920 r. rozpoczął pracę w Zarządzie Miejskim ${ }^{52}$.

46 Tamże.

47 Wielka księga adresowa stoł.[ecznego] Król.[ewskiego] Miasta Krakowa, stoł.[ecznego] Król.[ewskiego] Miasta Lwowa, król.[ewskiego] Woln.[ego] Miasta Podgórza 1909, red. S. Mikulski, J. Knapik, Kraków 1909, s. 30 (rozdz. III).

48 Wiadomości potoczne, „Kurier Poznański” nr 82 z 11 IV 1923.

49 APP, Kartoteka, sygn. 14339.

50 APP, Akta miasta Poznania, sygn. 433.

51 APP, Kartoteka, sygn. 14339.

52 APP, Akta miasta Poznania, sygn. 433. 
Dnia 15 maja 1920 r. do Poznania dotarła również żona Czarneckiego i małżonkowie zamieszkali pod adresem Rybaki $25^{53}$. Nowy pracownik Zarządu Miejskiego okazał się człowiekiem bardzo zapobiegliwym, ponieważ nie tylko wynegocjował wyższą pensję, ale zwrócono mu również koszty przeprowadzki - i to zarówno tej z grudnia 1919 r., jak i tej z maja $1920 \mathrm{r}^{54}$

Zgodnie z rozporządzeniem Ministerstwa b. Dzielnicy Pruskiej z 9 sierpnia 1920 r. w dniu 16 września 1920 r. Czarnecki złożył na ręce Prezydenta Miasta Poznania przysięgę służbową następującej treści:

Przysięgam Panu Bogu Wszechmogącemu na powierzonym mi stanowisku pożytek Państwa Polskiego oraz dobro publiczne mieć zawsze przed oczyma; władzy zwierzchniej Państwa Polskiego wierność dochować, wszystkich obywateli w równym mając zachowaniu przepisów prawa strzec pilnie, obowiązki moje spełniać sumiennie i gorliwie, rozkazy przełożonych wykonywać dokładnie, tajemnicy urzędowej dochować. Tak mi Panie Boże dopomóż $\dot{z}^{55}$.

W ciągu pierwszych dziewięciu miesięcy pracy w Poznaniu Czarnecki zorganizował i spolszczył wydział mieszkaniowy, sam prowadził wszelkie korespondencje w języku polskim. Z dniem 1 lutego 1921 r. powierzono mu dodatkowo prowadzenie spraw „Związku Miast”. W marcu tego roku Czarnecki zamierzał zmienić miejsce zatrudnienia na Wielkopolską Izbę Skarbową, jednak magistrat nie wyraził na to zgodny, a w lipcu przeniesiono go na stanowisko naczelnika biura gazowni miejskiej ${ }^{56}$.

Czarnecki, wracając do Poznania, był już chory, zdiagnozowana gruźlica dawała coraz bardziej o sobie znać i po niecałym roku od ostatniego awansu żona poinformowała władze miejskie, że 1 kwietnia $1923 \mathrm{r}$. jej mąż zmarł ${ }^{57}$. Klepsydry informujące o śmierci w imieniu magistratu i Rady Miejskiej wydrukowano w „Dzienniku Poznańskim”"58 i „Kurierze

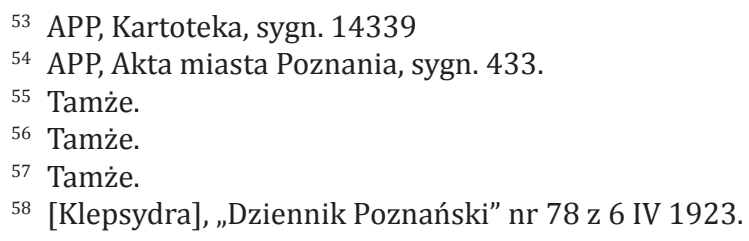


Poznańskim” ${ }^{59}$, w imieniu personelu gazowni miejskiej - w „Kurierze Poznańskim" ${ }^{\prime \prime}$, krótkie wspomnienie o działalności i pracy zmarłego opublikowano w „Kurierze”61. Byłego redaktora pochowano w Poznaniu na cmentarzu Bożego Ciała.

Po śmierci Czarneckiego jego żonie wypłacano tzw. zaopatrzenie wdowie na podstawie przepisów o emeryturze dla stabilizowanych urzędników Poznania z dnia 24 października 1922 r. $^{62}$

Koleje życia Sylwestra Czarneckiego nie odbiegają od życiorysów innych polskich redaktorów okresu porozbiorowego, chociaż niewielu z nich zdecydowało się na ucieczkę przed niemieckim wymiarem sprawiedliwości. W ciągu zaledwie 46 lat życia mieszkał w Śremie, gdzie się urodził, Poznaniu, Gliwicach, Dortmundzie, Kościanie, Krakowie, Lwowie i ponownie w Poznaniu. Peregrynacje takie ludzi pióra związanych z różnymi redakcjami były na początku XX w. w zaborze pruskim powszechne, w poszukiwaniu pracy, lepszych warunków życia przemieszczano się z miasta do miasta. Jednak decyzje o ucieczce zapadały rzadko i w wyjątkowo skrajnych warunkach. Czarnecki, opuszczając Kościan, miał za sobą jedynie wyrok skazujący go na dwa miesiące, a to w porównaniu z redaktorami odbywającymi kary zapadłe w sądach niemieckich nie było karą wysoką i szczególnie uciążliwą. Zagrożenie kolejnymi wyrokami, jak pisano, było duże i stąd decyzja o opuszczeniu miasta i wyjeździe do Galicji.

\section{Bibliografia}

\section{Źródła:}

Archiwum Państwowe w Poznaniu:

Akta miasta Poznania - sygn. 433: Akta osobowe pracowników Zarządu Miejskiego w Poznaniu z okresu międzywojennego (1919-1939); Kartoteka ewidencji ludności 1870-1931, sygn. 14339, 14406

Prezydium Policji w Poznaniu, sygn. 4947

Urząd Stanu Cywilnego Śrem - obwód miejski, sygn. 13

59 [Klepsydra], „Kurier Poznański” nr 78 z 6 IV 1923.

60 [Klepsydra], „Kurier Poznański” nr 77 z 5 IV 1923.

61 Wiadomości potoczne, „Kurier Poznański” nr 82 z 11 IV 1923.

${ }^{62}$ APP, Akta miasta Poznania, sygn. 433. 


\section{Gazety i czasopisma:}

„Dziennik Poranny” 1935

„Dziennik Poznański” 1905-1906, 1923

„Gazeta Gdańska” 1906

„Gazeta Polska” 1902

„Gazeta Toruńska” 1904

„Katolik” 1906

„Kurier Poznański” 1906, 1923

„Nowiny Raciborskie” 1906

„Orędownik” 1904-1906

„Polak” 1906

„Posener Tageblatt” 1906

„Postęp” 1906

„Praca” 1905-1906

\section{Publikacje drukowane:}

Bibliografia historii Polski XIX i XX wieku. T. 3: 1865-1918, vol. 2, Warszawa 2010. Wielka księga adresowa stoł.[ecznego] Król.[ewskiego] Miasta Krakowa, stoł. [ecznego] Król.[ewskiego] Miasta Lwowa, król.[ewskiego] Woln.[ego] Miasta Podgórza 1909, red. Stefan Mikulski, Józef Knapik, Kraków 1909.

\section{Fate Sylwester Czarnecki - Kościan, Lwów and Poznań}

ABSTRAKT: Sylwester Czarnecki (1877-1923) in the first years of his life he was a journalist working in newsrooms „Orędownik” (Poznań), gliwickiego „Głos Śląski” (Gliwice), „Dziennik Polski” in Dortmund and „Gazeta Polska” in Kościan. When numerous judgments in the process of the press threatened him in jail he escaped, first to Krakow and then to Lviv, where he stayed until the end of the First World War. In 1919, he returned to Greater Poland (Wielkopolska) and settled in Poznan. He worked as secretary of urban until his death.

KEYwordS: „Gazeta Polska”, Czarnecki Sylwester, Kościan, Lwów, Poland's newspapers, the Prussian sektor. 